EXEMPLARIa Classica

Journal of Classical Philology

20, 2016, pp. 257-265

ISSN 1699-3225

\title{
BOOK 1 OF MARTIANUS'S DE NUPTIIS: PHILOLOGY AND PHILOSOPHY IN A NEW EDITION AND COMMENTARY
}

Martianus Capella, Les noces de Philologie et de Mercure. Tome I: Livre I, texte établi et traduit par Jean-Frédéric ChEvalier, Paris: Les Belles Lettres, 2014, cxiv + 183 pp. ISBN 978-2-251-01467-8.

According to the style of the Budé series, this volume consists of a detailed introduction, a rather selective bibliography, and the critical edition of Martianus Capellas' De nuptiis Philologiae et Mercurii, equipped with a rich critical apparatus and a facing French translation. The shorter and simpler notes to the translation are printed at the bottom of the translation page, while the longer and more complex notes follow the edition and translation in the form of a more or less running commentary called "notes complémentaires". An index verborum and an index nominum (restricted to the ancient names) conclude the volume.

The introduction deals briefly with the dating and contents of Martianus's De nuptiis; a laudable aspect in it is the attention paid, to some extent, to Martianus's relation to philosophy, in particular Neoplatonism-a point which is virtually entirely missing from a similar recent work such as the edition and translation of the first two books of De nuptiis by Lucio Cristante and Luciano Lenaz. ${ }^{1}$. Chevalier, following Jean-Baptiste Guillaumin ${ }^{2}$, sticks to a dating between 420 and $430 \mathrm{CE}$ for the composition of De nuptiis (vii), thus disagreeing with Danuta Shanzer, who proposed a later dating in the Vandalic time.

A considerable part of the introduction is devoted to textual criticism (xlix-lxxxvii), as one could expect in a critical edition. The edition is based on the collation of about twenty mss. A long gap in the ms. tradition of Martianus, from the fifth to the ninth century, leaves us irremediably remote from the archetype. Already in the late fifth century, Securus Melior Felix in his subscriptio at the end of Book 1 complained about the faulty state of the mss. available to him in Rome: ex mendosissimis exemplaribus emendabam. The early-ninth-century mss. that represent the earlier state

${ }^{1}$ Martiani Capellae De Nuptiis Philologiae et Mercurii Libri I-II, ed. L. Cristante, transl. L. Lenaz, comm. L. Cristante, I. Filip, L. Lenaz, Hildesheim 2011: see my review in The Classical Review 63, 2013, 477-9.

2 J.-B. Guillaumin, "Néoplatonisme et encyclopédisme dans l'œuvre de Martianus Capella", Revue des Études Latines 86, 2008, 167-90. 
of the text we can reconstruct ${ }^{3}$ are riddled with errors; hence all the work of correction and glossing during the ninth and tenth centuries. Chevalier praises James Willis' Teubner edition-which I used as a basis for my translation and commentary, as well as for my edition of Martianus's commentators ${ }^{4}$-as a positive advancement with respect to Dick's older Teubner edition, revised by Préaux. Willis privileged the older mss. Chevalier also values Jean-Baptiste Guillaumin's work on Martianus's stemma codicum, but he thinks that in the case of Martianus it is impossible to establish a ms. genealogy with any degree of certainty. This scepticism, albeit perhaps somewhat exaggerated, is nevertheless justified, especially for the cross-contaminated ms. tradition from the tenth century onwards.

However, Chevalier reaches probable conclusions when he identifies $\mathrm{W}$ as representative of the earliest layer of the text that we can reconstruct, $R$ as representative of a very close stage, $\mathrm{A}$ and $\mathrm{H}$ as representing the following stage, and the corrections adduced to the WRAH tradition by $\mathrm{DBT}^{5}$ as constitutive of yet another stage. WRAH are thus the testimonia closest to the archetype, but with $\mathrm{AH}$ depending on a ms. that had introduced some mistakes. A further layer is represented by a group of mss., $\mathrm{VCEF}^{6}$, which are posterior to WRAHDBT, since they include corrected readings, but without any traces of corrections. Basing himself on the work of Sinead O'Sullivan, Chevalier determines that $\mathrm{V}$ is anterior to $\mathrm{E}, \mathrm{C}$ depends on $\mathrm{V}$, and $\mathrm{F}$ has a specific derivation. From the tenth century, the text of De nuptiis assumed a relatively stable shape, grounded in the authority of Eriugena and Remigius of Auxerre, but from this stage of horizontal contamination onward, it is no longer possible to determine precisely the history of the text (lxxv). Chevalier also concludes plausibly that in the original title of Martianus's prosimetrum

${ }^{3}$ W (Paris, Bibliothèque Nationale, Parisinus Latinus 13026, early ninth cent., containing only the poems), R (Karlsruhe, Badische Landesbibliothek, Reichenauensis 73 or Augiensis 73, first half of the ninth cent., containing the whole De nuptiis), A (London, British Library, Harleianus 2685, second half of the ninth century), and $\mathrm{H}$ (Vatican City, Biblioteca Apostolica Vaticana, Reginensis Latinus 1987, ninth century, never subject to collation for Book 1 of $D e$ nuptiis before Chevalier's edition).

${ }^{4}$ Marziano Capella: Nozze di Filologia e di Mercurio, essay, edition and translation, commentary, appendixes, and bibliography, Milan 2001; Tutti $i$ commenti a Marziano Capella: Scoto Eriugena, Remigio di Auxerre, Bernardo Silvestre e anonimi, essays, editions and translations, commentaries, appendixes, and bibliography, Milan 2006.

${ }^{5} \mathrm{D}$ (Paris, Bibliothèque Nationale, Latinus 8670, mid-ninth century, with the anonymous glosses-formerly attributed to Dunchad or Martinus of Laon-and glosses from Remigius of Auxerre), B (Bamberg, Staatsbibliothek, Class. 39, second half of the ninth century, with non identified glosses), T (Vatican City, Biblioteca Apostolica Vaticana, Reginensis Latinus 1535, mid-ninth century or slightly later, with the anonymous glosses, not yet used in a collation for Book 1 of De nuptiis before Chevalier).

${ }^{6} \mathrm{~V}$ (Leiden, Universiteitsbibliothek, Vossianus Latinus F. 48, from the years 820-830, with the anonymous glosses), C (Paris, Bibliothèque Nationale, Latinus 8669, with many glosses), E (Besançon, Bibliothèque Municipale, 594, mid-ninth century, with many glosses), F (Oxford, Bodleian Library, Laud. Lat. 118, mid-ninth century or slightly later, with many glosses). 
the name of Mercury did not appear, since it is absent from the earliest mss. (lii). AHDT read De nuptiis Philologiae, and W De Philologia; R and B lack the title. Also intermediate mss. such as VEFL have no references to Mercury in the title.

The rest of the introduction (lxxv-lxxxvii) is devoted to the description of other mss. that have been consulted for the present critical edition, and to a list of 96 differences in readings and conjectures between this and the other preceding editions. A bibliography, divided into editions, translations, and studies is provided on xc-cxi. It comprises the main works, including my 2001 translation and commentary and 2006 edition of the Mediaeval commentators on Martianus, as well as other works of mine, but curiously enough it does not mention Mariken Teeuwen's and Sinead O'Sullivan's rich edited volume, Carolingian Scholarship and Martianus Capella, Turnhout 2012, nor does it include Sinead O'Sullivan's entry on Martianus in Catalogus translationum commentariorum. Mediaeval and Renaissance Latin translations and commentaries: annotated lists and guides, Washington DC 2014 (Addenda et Corrigenda to "Martianus Capella”, by Cora E. Lutz, CTC vol. 2, 367).

After a conspectus siglorum, the critical edition and translation are generally accurate, and the bottom-page notes and the notes complémentaires are frequently instructive and useful. Chevalier's translation is the second French translation of Book 1 of De nuptiis, after V. Di Natale's translation of Books $1-2^{7}$, and is laudable also in its effort to render somehow the difference between prose and verse in Martianus's prosimetrum. In the introduction, the short notes, and the commentary Chevalier sometimes makes use of the Mediaeval commentators, although very rarely and virtually only Eriugena's and Remigius of Auxerre's commentaries (e.g., Remigius features in fn. 13 on p. 2 ; fn. 394 p. 20 ; fn. 501 p. 27 ; n. 8 p. 45 , etc.). The footnotes, and especially the notes complémentaires, are often found in conversation with Danuta Shanzer's commentary, with both agreements and disagreements, and with my 2001 commentary on Martianus, my 2006 edition, with essays and commentary, of the commentators on Martianus, and other works of mine, especially concerning the Stoic allegorical tradition, e.g. about the

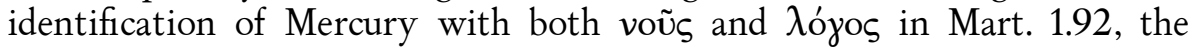
latter being a common allegorisation of Hermes in Stoicism ${ }^{8}$, or about the allegorisation of Apollo as harmonising the cosmos in Mart. 1.66, with reference to Cornutus $32^{9}$, or else about the allegoresis of Jupiter as ether, pure fire, and Hephaestus as fire mingled with air ${ }^{10}$, and again about Cornutus's

${ }^{7}$ Dédale 11-12, 2000, 454-510.

${ }^{8}$ N. 712, p. 39, with reference to my Anneo Cornuto: Compendio di Teologia Greca, Milan 2003, 207-15.

${ }_{9}^{9}$ N. 554, p. 134, with reference to Anneo Cornuto, 279-87.

${ }^{10}$ N. 477, p. 118, with reference to Anneo Cornuto, 226-31. 


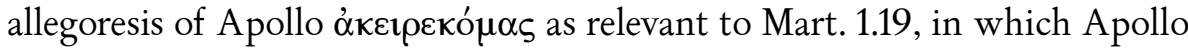
is called $\dot{\alpha} \kappa \varepsilon \rho \sigma \kappa o ́ \mu \eta \varsigma^{11}$. A reference to the Stoic allegorical tradition would have been particularly relevant to n. 548 pp. 133-4, concerning Jupiter's description in Mart. 1.66. The interpretation of Jupiter/Zeus's body as the whole universe indeed corresponds to the Stoic allegorisation of Zeus as the Pneuma and Logos that extends throughout all cosmic regions-and assumes the names of various minor deities in the various regions, being however the same Logos-Pneuma-Zeus throughout. Also, in n. 460 p. 116, commenting on Mart. 1.39, Chevalier correctly remarks: "L'air, symbolisé par Junon, est comme attaché à l'éther, symbolisé par Jupiter. Jupiter domine son épouse comme l'ether domine l'air." It would have been worth adding here that this was a typical Stoic allegoresis, reflected in Cornutus, Comp. Theol. Gr. 3.

The notes complémentaires often acknowledge and follow also other suggestions I offered in my commentary, e.g. in n. 20 p. 48 the parallel between Martianus and Claudian I indicated ${ }^{12}$; in n. 520 p. 128 the references to Dionysius of Halicarnassus, Ovid, Lactantius, and Augustine I proposed for Mart. $1.56^{13}$; in n. 651 p. 147 the parallel between Mart. 1.77 and Cicero Verr. 2 I pointed out ${ }^{14}$; in n. 491 p. 121 the references to Cicero and Firmicus Maternus I proposed for Mart. $1.45^{15}$; in n. 84 p. 62 the reference to Ovid Met. 9.693 I offered for Mart. $1.4^{16}$; in n. 357 p. 104 the parallel with Apuleius Met. 6.6 I proposed for Mart. $1.26^{17}$; in n. 491 p. 123 the distinction between Penates and Dei Consentes in Mart. 1.45 I suggested $^{18}$; in n. 721 p. 160 the difficulty in the construction of dissona, nominative or accusative, in Mart. 1.92 that I remarked, as well as the choice of referring dissona to elementa, which I also made ("gli elementi dissonanti")19. Likewise the same notes sometimes quote, and approve of, my translation in difficult points, e.g. in n. 30 p. $50-51$; in n. 602 p. 141 ; in n. 681 p. 154 ("che sempe scorre con flusso alterno" in Mart. 1.88, based on the reading fluxu); in n. 79 p. 60 ("la dea argiva" in Mart. 1.4, based on a correction of Argionam into Argivam); in n. 268 p. 93 ("dinnanzi a lui" in Mart. 1.16); in n. 37 p. 54 (my interpretation of nictantis antistitis in Mart. 1.2 as a reference to the still sleepy eyelids of a priest early in the morning, before opening the temple) ${ }^{20}$.

In n. 34, p. 52, Chevalier refers to an episode in Book 7 to support his interpretation: the entrance of Paideia with a lady of exceptional beauty,

${ }^{11}$ N. 295, p. 97 , with reference to Anneo Cornuto, 280-83.

${ }^{12}$ In Marziano Capella: Nozze, xciii.

${ }^{13}$ Ibid. 755.

${ }^{14}$ Ibid. 765.

${ }^{15}$ Ibid. 751-2.

${ }^{16}$ Ibid. 725.

${ }^{17}$ Ibid. 740.

${ }^{18}$ Ibid. 36.

${ }^{19}$ Ibid. 50-1, 772-3.

${ }^{20}$ Ibid. 2-3. 
namely Arithmetica. I would add that the very reason for this beauty comes from the order and proportion symbolised by arithmetic, a point also emphasised by the Platonising Augustine in De ordine. In n. 36 p. 53 Chevalier

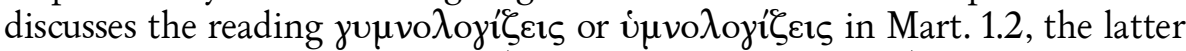
being both his and my choice (I translated "innologizzi"), and the former being Préaux's suggestion. However, it would have been good to present in the note all the evidence, including the main Mediaeval commentaries, which are

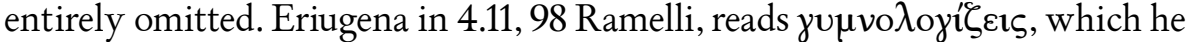

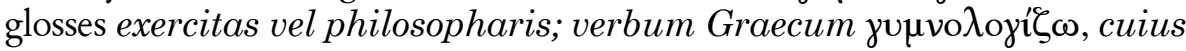
propria interpretatio est exercito. Eriugena, in line with Origen's 'zetetic' philosophical style (which directly inspired his Periphyseon), interprets the reading $\gamma u \mu v o \lambda$ oyícis found in his mss. as "you exercise," in the sense of "you practice philosophy," mainly regarded as an exercise ( $\gamma v \mu \nu \alpha \sigma \tau \imath \kappa \eta ')$ of

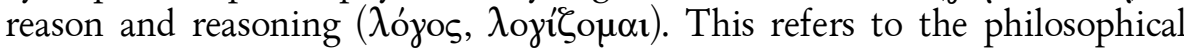
interpretation of the opening hymn of Book 1, which under the allegorical veil of myth likely alludes to Neoplatonic henology. Indeed, Chevalier himself acknowledges (xix-xxiii) that this inaugural hymn of De nuptiis is deeply embedded within the Platonic tradition. Now this, I observe, offers a programmatic philosophical allegiance. I think that Martianus here, by insisting on Hymenaeus's unifying function, refers to Neoplatonic henology (doctrine of the One) and protology or doctrine of the metaphysical first principles, in which the One or है $v$ functions as transcendental culmination ${ }^{21}$.

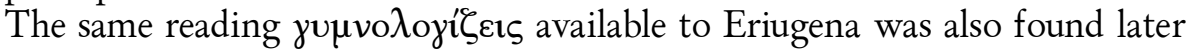
by Remigius of Auxerre in his own exemplars of Martianus. In 4.10, 875 Ramelli, Remigius glosses gymnologisis with id est ratiocinaris, with the same reference to the exercise of reason that was proposed by Eriugena. The short explanation that follows also resonates with that of Eriugena: $a$ Graeco quod est gymnologiso, id est exerceo. Hinc gymnus dicitur nudus et gymnasium locus exercitationis. A similar reading, such as gymnologisas, probably corrupted into gignalogias, seems to have been available still to the author of the commentary on Martianus attributed to Bernardus Silvestris, 1822 Ramelli: Gyeas Greca interpretatione nudus est, unde gignasium quasi nudum certamen. Logos vero oratio. Idem est itaque gignalogias quod nude loqueris, because Martianus's son, who is speaking here, looked only at the myth (solam fabulam), without considering its philosophical interpretation discoverable through allegoresis. The reading gignalogias was also the one known to the anonymous author of the Berlin-Zwettl commentary on Martianus related to the School of Chartres, who, at 2120 Ramelli, supplies exactly the same explanation as that given by (Ps.?) Bernardus. Neither of the last two commentaries is ever taken into account in Chevalier's notes.

\footnotetext{
${ }^{21}$ On this, see my "Harmony between arkhē and telos in Patristic Platonism", International Journal of the Platonic Tradition 7, 2013, 1-49.
} 
More could have been said in the notes complémentaires from the philosophical viewpoint, too. And mediaeval commentaries such as those by Eriugena, Remigius of Auxerre, Bernardus Silvestris, and the School of Chartres could have been used much more, and more beneficially. For instance, at least a systematic investigation into the allegorisations of Philology and Mercury provided by the main commentators would have been particularly relevant to the overall interpretation of Martianus's allegorical prosimetrum. John the Scot Eriugena at the very beginning of his commentary, p. 3 Lutz, 94 Ramelli, programmatically identifies Philology with "love for the logos" or reason, and Mercury with "eloquence of discourse": Philologia quippe studium rationis, Mercuriusve facundiam sermonis insinuat, quasi simul veluti quodam conubio in animas sapientiae studia discentium convenerit. Both must be joined in the souls of those who learn: studia sapientiae is the literal translation of $\varphi$ i $\lambda$ oбopia, love for wisdom. The same interpretation emerges from another set of glosses with which Eriugena equipped Martianus's De nuptiis-a work which is preserved in an Oxford ms. edited by Édouard Jeauneau ${ }^{22}$ and which is never taken into account by Chevalier, nor even mentioned in his bibliography. Here, on fol. 1r-v, 781 Ramelli, Eriugena identifies again Hermes-Mercury with sermo, and Philology with studium sapientiae, "love for Wisdom," i.e. in fact philosophy. Here Eriugena also supplies the Greek etymology of

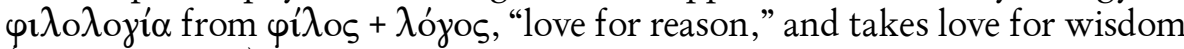
(i.e. philosophy) and love for reason as synonyms. In his Adnotationes in Marcianum 39.15, 181 Ramelli, toward the end of Book 1, Eriugena identifies Mercury also with Nous or Intellect ${ }^{23}$. Jupiter, indeed, calls Mercury honos sacer, which Eriugena reads either as honos sacer or as ó voũs sacer: honos sacer] honor sanctus, vel ò voũs sacer: ò articulus, voũs mens: sacra mens. Remigius of Auxerre at the very beginning of his commentary, 868 Ramelli, like Eriugena at the opening of his own, identifies Philology with sapientia et ratio and Mercury with facundia et sermo, noting the excellence of the former, viz. philosophy, over the latter, viz. rhetoric: Philologia ergo ponitur in persona sapientiae ac rationis, Mercurius in similitudine facundiae et sermonis. Ut autem Cicero dicit, eloquentia, $i d$ est sermonis copia, sine ratione et sapientia nocet aliquando, raro aut numquam prodest; sapientia vero sine eloquentia prodest semper, numquam obest. The commentary ascribed to Bernardus Silvestris, 1762 Ramelli, also identifies Mercury with eloquence and Philology with reason: sermonem quidem dicit Mercurium ... Philologia humanae rationis

${ }^{22}$ Oxford, Bodleian Library, Auct. T. 2. 19, ed. É. Jeauneau, Quatre thèmes érigéniens. Conférence Albert-Le-Grand 1974, Montréal-Paris 1978, 101-66. These glosses cover only Book 1 of De nuptiis, precisely the one edited by Chevalier.

${ }^{23}$ Chevalier is right to note this, albeit en passant, in n. 717 p. 159. 
Graecum est vocabulum. The author adds that, just as Pythagoras called philosophy "love for wisdom" and not wisdom itself, so did also Martianus call Philology "love for the Logos" or reason, and not Logos/ratio itself. Similar remarks are to be found in the anonymous Berlin-Zwettl commentary related to the School of Chartres, 2098 Ramelli, where Mercury is allegorised as sermo, and Philology is interpreted as "love for the Logos," as a mitigation of Logos/ratio itself, similar to Pythagoras' mitigation of wisdom into "love for wisdom," namely philosophy.

In a number of minor points, concerning both textual and translation issues in De nuptiis, checking the Mediaeval commentaries on Martianus may prove useful. For instance, in Mart. 1.5 the interpretation of dum paret pluribus is controversial. It can mean both "this appears clear / is evident to the majority" and "he [i.e. Mercury] obeys the majority". Chevalier, n. 86 p. 62, privileges the latter translation, but it would have been useful for him to adduce at least Remigius of Auxerrre's rendering of this sentence: dum paret, id est oboedit et obtemperat, pluribus (6.7, 881 Ramelli). For my part, I preferred the former interpretation and translated "questo alla maggioranza appare chiaro", which is supported by the reading patet and the exegesis found in the commentary attributed to Bernardus Silvestris, 1875 Ramelli: dum ipse patet pluribus, id est dum ad placitum plurium significat quia amicitias et coniugia hominum videt.

Another interesting case, among a number thereof, concerns Martianus's presentation of Psyche or Soul as the daughter of Endelechia-EndelichiaEntelechia-Entelecheia and the Sun in 1.7. Chevalier in n. 113 pp. 66-67 rejects Scevola Mariotti's and Luciano Lenaz's reading endelichiae and follows Danuta Shanzer's and others' reading endelechiae, accepting Béatrice Bakhouche's translation, "l'âme cosmique en mouvement". Indeed, that Entelecheia represents the world soul of the Platonic tradition, probably named by an Aristotelian technical term such as $\varepsilon \nu \tau \varepsilon \lambda \varepsilon^{\prime} \chi \varepsilon 1 \alpha$, is what emerges from the Neoplatonist Eriugena's commentary, 7.10, 106 Ramelli, although, again, Chevalier does not adduce it. After reporting Calcidius's etymology ${ }^{24}$

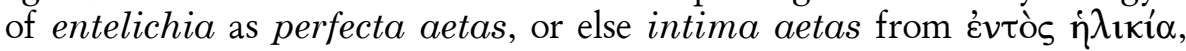
Eriugena explains that Plato called Entelechia the world soul: Generalem quippe mundi animam Entelechiam Plato nominat, ex qua speciales animae, sive rationabiles sint sive ratione carentes, in singulas mundani corporis partes, sole administrante vel potius procreante, procedunt, ut Platonici perhibent. Quorum sectam Martianus sequitur, asserens Psychen, hoc est animam, Entelechiae ac Solis esse filiam. Here as elsewhere, Eriugena points out Martianus's Platonic allegiance. Remigius of Auxerre in his commentary, 7.10, 884 Ramelli, introduces also Aristotle's technical meaning of $\varepsilon v \tau \varepsilon \lambda \varepsilon^{\prime} \chi \varepsilon 1 \alpha$ as act/actuality or perfection (as opposed

${ }^{24}$ In his Commentary on Plato's Timaeus, 219, 220, and 222. 


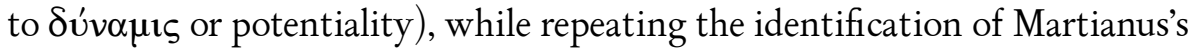
Entelechia with Plato's world soul: Endelychiam secundum Calcidium perfecta aetas, secundum Aristotelem absoluta perfectio interpretatur. Plato tamen Endelychiam animam mundi dicit. Et dicta Endelychia quasi endos lechia, id est intima aetas. Philosophi namque animam mundi vocant illum spiritum quo vegetatur et regitur mundus ... Ex hac ergo anima mundi secundum philosophos ministrante vel inserviente sole dicunt gigni omnes speciales animas, rationales sive irrationales. Hoc ergo sciens Martianus finxit Psychen Solis et Endelychiae filiam. The commentary attributed to Bernardus Silvestris, 1900 Ramelli, interprets Endelichia as eternity and identifies it with God's Wisdom as the formal cause of the soul/Psyche: Siche enim anima ... Endelichia vero intima aetas interpretatur, Sapientia vero Dei aetas, quasi aevitas, eo quod absque initio et fine et temporali successione existit. ... Intima vero dicitur ideo quia ei [sc. Deo] absque doctrina innata est. ... Endelichia ergo est mater Siches, id est Dei Sapientia est causa animae non materialis sed formalis. Here the interpretation of Entelechia as the world soul has disappeared, this being replaced by the divine Wisdom, Christ, as the creator of all souls. The same happens in the Berlin-Zwettl commentary related to the School of Chartres, 2158-59 Ramelli ${ }^{25}$.

One last example concerns the exegesis of Pallas as neither generated nor generating (as Heptad) in Mart. 1.40. In n. 470 p. 117 no commentator is cited, but Eriugena had a long development on this point in 25.14-15, 153-54 Ramelli. Now this divinity, which neither is generated nor generates, would seem to be the highest, transcendent divinity in Middle and Neoplatonism, so much so that in his own Periphyseon Eriugena defined the Godhead in its transcendence as "the nature that is not generated and does not generate"; God is the first principle of all and the end of all. This further supports the hypothesis that Pallas represents the supreme Neoplatonic principle, higher than Jupiter. Chevalier himself indeed realises that the pure light from which Pallas comes in Mart. 1.39 refers to the world of the superior hypostases (xli). This exegesis seems to me to be warranted, once again, by Eriugena's interpretation. In Adnotationes in Marcianum 24.13, 151-52 Ramelli, Eriugena reads the luminous, superior place from which Pallas descends as the highest place, the seat of immortal virginity (since the first principle produces nothing, as Eriugena insists also in 25.14-15), purest, luminous, and brightest, the most splendid ethereal region: a superioribus mundi partibus ... de vertice mundi immortalis virginitas ... purgatioris vibatiorisque luminis loco, hoc est splendidioris aetheris loco. This is also why the throne of Pallas is represented by Martianus as loftier than Jupiter's (the

${ }^{25}$ Psyche is the soul, and Entelichia the divine Wisdom, which created it from nothing. Plato called it intima aetas as though it were aevitas, "eternity". 
second, productive Middle/Neoplatonic principle), just as Jupiter's throne is higher than that of Juno and the other deities, since Pallas has the remotest and purest of the spheres (Adn. In Marc. 24.15, 152 Ramelli).

However, there are also many fine points and thorough treatments in the notes and commentary, and typos are rare. For instance, Chevalier is correct to see in Mart. 1.10 'une allusion au discrédit jeté par les chrétiens sur les lieux oraculaires' (n. 177 p. 79), and to comment on the same passage as follows: "comme la Sibylle avait été christianisée, il n'est pas surprenant qu'elle ait disparu de l'univers néoplatonicien dépeint par Martianus" (n. 179 p. 79). Regarding Mart. 1.7, Chevalier rightly notes (n. 148 p. 72) that the vehiculum of the soul, Psyche, is the ox $\chi \mu \alpha$ that, according to the Neoplatonists, allows the soul to re-ascend to the One ${ }^{26}$. In n. 403 p. 110 , Chevalier evokes Calcidius's exposition of the Platonic theory concerning providence, destiny, and freewill in In Tim. 142-158. This remark is certainly pertinent. However, while Calcidius was surely known to Eriugena, who explicitly cited his commentary on the Timaeus in his own commentary on Martianus, it is uncertain whether Martianus himself was familiar with Calcidius's work. On the whole, this volume provides a valuable edition, also based on mss. never used so far in a collation for Book 1 of De nuptiis, a fine translation, and a helpful commentary, for which all Martianus scholars should be very grateful to Jean-Frédéric Chevalier.

ILARIA L.E. RAMELLI Catholic University; Angelicum; Oxford University ilaria.ramelli@unicatt.it; i.l.e.ramelli@durham.ac.uk

${ }^{26}$ See my “Iamblichus, De anima 38 (66,12-15 Finamore-Dillon): A Resolving Conjecture", Rheinisches Museum 157, 2014, 106-11. 